\title{
Water Quality and Ecotoxicity Assessment in Surface Waters from Cubatão River and Surroundings, São Paulo, Brazil
}

\section{Vanessa Silva Granadeiro Garcia ${ }^{*}$, Eduardo Toshio Domingues Matsushita ${ }^{2}$, Letícia Cristina Alves Mesquita ${ }^{1}$, Deborah Inês Teixeira Fávaro ${ }^{3}$, Sueli Ivone Borrely ${ }^{1}$}

\author{
${ }^{1}$ Instituto de Pesquisas Energéticas e Nucleares, IPEN-CNEN/SP, Centro de Tecnologia das Radiações, Cidade Universitária, \\ São Paulo, Brazil \\ ${ }^{2}$ Instituto de Física da Universidade de São Paulo, IF/USP, Butantã, São Paulo, Brazil \\ ${ }^{3}$ Instituto de Pesquisas Energéticas e Nucleares, IPEN-CNEN/SP, Laboratório de Análises por Ativação Neutrônica, \\ Cidade Universitária, São Paulo, Brazil \\ Email: *vanessagranadeiro@gmail.com
}

How to cite this paper: Garcia, V.S.G., Matsushita, E.T.D., Mesquita, L.C.A., Fávaro, D.I.T. and Borrely, S.I. (2017) Water Quality and Ecotoxicity Assessment in Surface Waters from Cubatão River and Surroundings, São Paulo, Brazil. Journal of Water Resource and Protection, 9, 1510-1525.

https://doi.org/10.4236/jwarp.2017.912096

Received: October 31, 2017

Accepted: November 27, 2017

Published: November 30, 2017

Copyright (c) 2017 by authors and Scientific Research Publishing Inc. This work is licensed under the Creative Commons Attribution International License (CC BY 4.0).

http://creativecommons.org/licenses/by/4.0/

\begin{abstract}
The monitoring of water bodies means the attempt of protecting vulnerable groups of organisms inhabiting streams and rivers. Industrial and domestic discharges may worsen the water quality and affect biological balance, structure and the functioning of the ecosystem. Cubatão City, is one of the largest industrial centers in Brazil and in Latin America, where the constant discharge of effluents into Cubatão River and its tributaries caused a degradation scenario in the hydrographic basin of the region. The objective of this study was to evaluate the acute and chronic effects of surface water from Cubatão River and two of its tributaries (Perequê and Pilões) by ecotoxicological assays. In addition, physical chemical parameters were analyzed. Ceriodaphnia dubia and Vibrio fischeri were exposed-organisms during the studied period. The study was conducted between 2010 and 2011 in four campaigns and nine sites along the basin of Cubatão River. The ecotoxicity was measured by $\mathrm{Vi}$ brio fischeri bioluminescence, EC50 values ranging from $31.25 \%$ to $71.61 \%$. In contrast, based on a bioequivalence t-test statistical analysis, the results obtained with Ceriodaphnia dubia revealed no toxicity in the sampling sites. A critical analysis of raw data of luminescence was carried out showing higher values during the $2^{\text {nd }}$ campaign. From the numbers obtained for physical-chemical parameters P5 was far the worst due to chlorides, hardness and conductivity. From the Pearson correlation analysis carried out with toxicity to $V$. fischeri and the physical chemical parameters, the dissolved oxygen in water resulted in a moderate positive correlation. Sediment contamination was also demonstrated in the region.
\end{abstract}




\section{Keywords}

C. dubia, Cubatão River, Ecotoxicity Assays, V. fischeri, Water Quality

\section{Introduction}

Cubatão City is located in São Paulo State, Brazil, and it is part of the Metropoli$\tan$ Region of Baixada Santista, being bordered by the municipalities of São Bernardo do Campo, Santo André, Santos and São Vicente. Cubatão River basin is located halfway between Grande São Paulo and Baixada Santista with an area of $177 \mathrm{~km}^{2}$, approximately. Cubatão River is one of the most expressive rivers of the basin and, with the Pilões River, they account for about $80 \%$ of the water for Santos population supply. In addition, they supply water to the industrial center of Cubatão (the largest chemical and petrochemical complex in Brazil). Cubatão River basin is located in the area of Mata Atlântica, one of the richest and most expressive biomes in Brazil and in other countries, such as Paraguay and Argentina.

This expressive industrial center has discharged hundreds of toxic compounds in the environment since the 40 's, through discharges of industrial and domestic effluents. This center is one of the largest in Latin America with a variety of industrial fields such as petrochemicals, steel, fertilizer production and chemical industries. These are some of the reasons why Cubatão River has undergone dramatic changes over the years, what affected the aquatic biota.

The anthropogenic contribution to the contamination of water and sediments in this region was reported in different studies. [1] point out high concentration of organic contaminants in the sediments near to Cosipa channel, as polycyclic aromatic hydrocarbons (PAHs), 109.2 to $733.7 \mu \mathrm{g} \cdot \mathrm{kg}^{-1}$ dry weight, offering risks to biota. The presence of radionuclide, particularly uranium, thorium and hafnium, was shown by [2]. [3] showed that Fe and Zn were the main indicators of anthropogenic contribution in the sediments of Baixada Santista, and Th, Ce, As, $\mathrm{U}$ and others elements have a high background level in the region. Mercury is an important reported pollutant, concentrations between $1.57 \pm 1.73 \mathrm{ppm}$ in sediments of the Cubatão River are demonstrated by [4]. [5] notes that different elements have a homogeneous spatial distribution in sediments, with the highest values at the Cubatão Industrial Complex.

The contamination in the Baixada Santista region including Cubatão River basin, can be affect directly the Santos-São Vicente estuary. Research shows that pollution in this region has increased considerably over the years: hematological changes and cytogenotoxic effects in tropical estuarine fish Centropomus parallelus [6] [7], gradient of increasing contamination for metals and organic compounds in sediments and impoverishment of benthic community [8]; high concentrations of linear alkylbenzenes in sediments [9].

Water and sediments toxicity assessment may give relevant information even 
as a result of pollutants not easy to identify. Monitoring Cubatão River was really important to show the possible effects of the contaminants in the aquatic ecosystem and especially to propose mitigating actions.

The objective of this paper was to assess toxic effects of water to $C$. dubia and $V$. fischeri at nine sites sampled at Cubatão, Perequê and Pilões Rivers. In addition, physical chemical parameters, of water, such as dissolved oxygen, $\mathrm{pH}$, turbidity, total organic carbon, were analyzed. The importance of using two toxicity assays was also discussed as well as their sensibility to the pollutants detected during the study. Sediment contamination was also analyzed.

\section{Materials and Methods}

Nine sites along the basin of the Cubatão River were assessed: seven sites belong to Cubatão River and two sites to its tributaries (Perequê River and Pilões River). The sampling period was March and August 2010 and February and June 2011, including periods of rainy summer (March 2010 and February 2011) and drier periods of winter (August 2010 and June 2011).

In the $1^{\text {st }}$ campaign, water samples were collected at three sites in Cubatão River identified as P0, P2 and P5. From the $2^{\text {nd }}$ campaign the remaining sites were included in the study (P1, P3, P4, P6, Perequê River-PE and Pilões River-PI). Geographical references (latitude and longitude) were shown at Table 1. The election of sampled sites comprehended the spring region (P0) and all sites where important influences would be related to occupation of the area until the river meet the estuary (P5). Figure 1 shows the localization of the sampling sites along the basin of the Cubatão River. It is also possible to see the occupied area, very close to the river.

Table 1. Geographical references of the sampling sites and important activities references.

\begin{tabular}{|c|c|c|c|}
\hline Points & Latitude & Longitude & Description of the sampling site \\
\hline P0 & $\mathrm{S} 23^{\circ} 54^{\prime} 53.3^{\prime \prime}$ & WO $46^{\circ} 29^{\prime} 43.8^{\prime \prime}$ & Cubatão River-Ecological Park Itutinga Pilões. \\
\hline P1 & S235' $46.9^{\prime \prime}$ & WO $46^{\circ} 26^{\prime} 48.6^{\prime \prime}$ & $\begin{array}{l}\text { Hydroelectric Power Plant } \\
\text { Henry Borden. (Channel II) }\end{array}$ \\
\hline $\mathbf{P} 2$ & $\mathrm{~S} 23^{\circ} 52^{\prime} 50.3^{\prime \prime}$ & WO $46^{\circ} 26^{\prime} 48.1^{\prime \prime}$ & Water treatment station. \\
\hline P3 & $\mathrm{S} 23^{\circ} 52^{\prime} 47.2^{\prime \prime}$ & WO $46^{\circ} 26^{\prime} 54.5^{\prime \prime}$ & $\begin{array}{l}\text { Hydroelectric Power Plant Henry Borden } \\
\text { (EMAE). (Escape Channel I) }\end{array}$ \\
\hline P4 & $\mathrm{S} 23^{\circ} 52^{\prime} 45.8^{\prime \prime}$ & WO $46^{\circ} 25^{\prime} 19.2^{\prime \prime}$ & $\begin{array}{l}\text { Municipality Center-Cubatão, near to } \\
\text { "Ana Costa" Hospital and downstream of } \\
\text { CBE-Estireno. }\end{array}$ \\
\hline P5 & $\mathrm{S} 23^{\circ} 52^{\prime} 39.5^{\prime \prime}$ & WO $46^{\circ} 24^{\prime} 43.1^{\prime \prime}$ & Cubatão River-Carbocloro S.A. saline \\
\hline P6 & $\mathrm{S} 23^{\circ} 52^{\prime} 49.4^{\prime \prime}$ & WO $46^{\circ} 25^{\prime} 36.7^{\prime \prime}$ & $\begin{array}{l}\text { Pres. R. Bernardes Refinery and } \\
\text { Fosfertil Fertilizer SA. }\end{array}$ \\
\hline PI & $\mathrm{S} 23^{\circ} 54^{\prime} 27.1^{\prime \prime}$ & WO $46^{\circ} 29^{\prime} 31.6^{\prime \prime}$ & Pilões River-Itutinga Pilões Park. \\
\hline $\mathrm{PE}$ & $\mathrm{S} 23^{\circ} 52^{\prime} 00.7^{\prime \prime}$ & WO $46^{\circ} 25^{\prime} 05.8^{\prime \prime}$ & $\begin{array}{l}\text { Perequê River-downstream } \\
\text { Perequê Ecological Park. }\end{array}$ \\
\hline
\end{tabular}




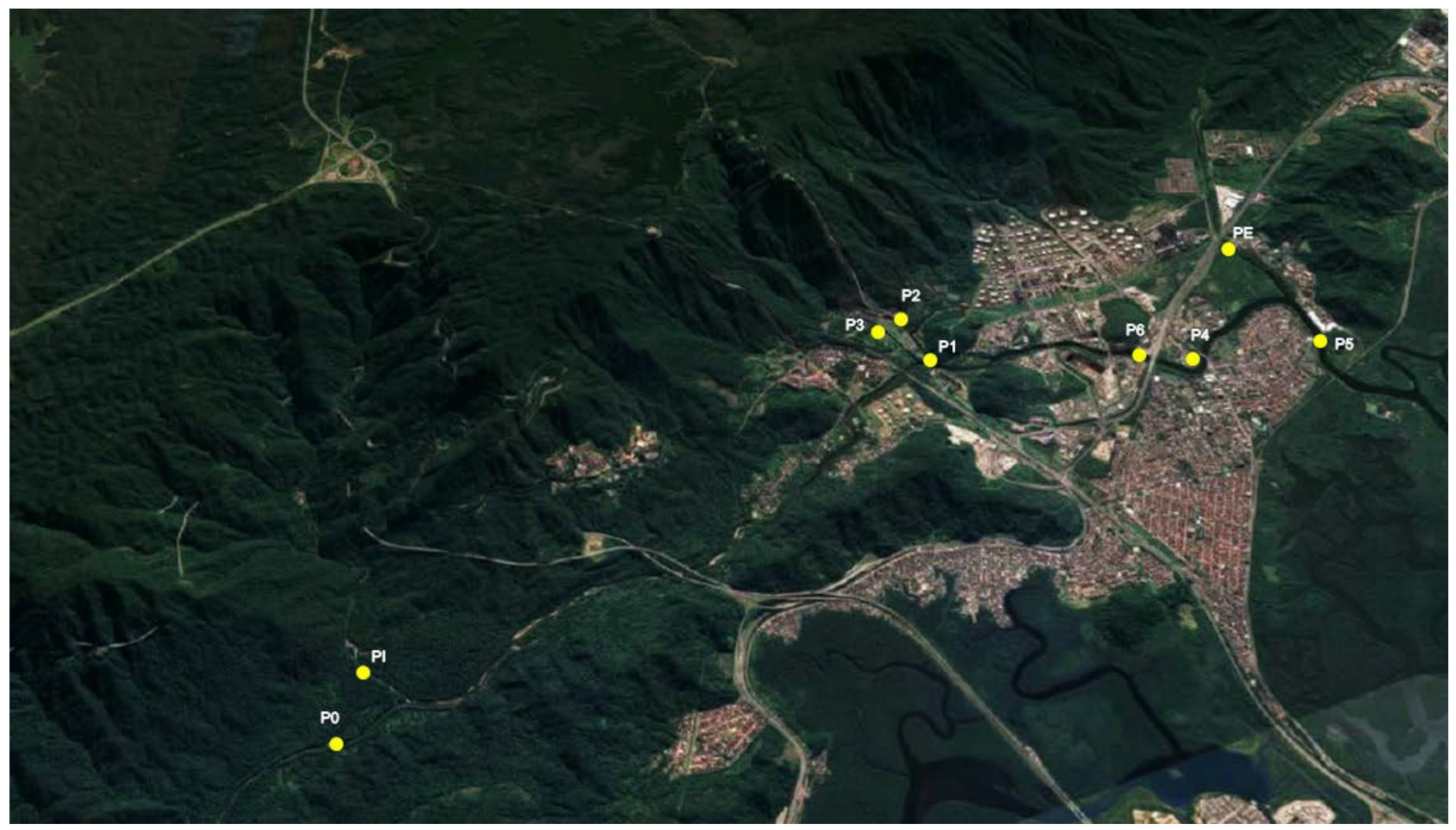

Figure 1. Photograph indicating the geographical position for each site at Cubatão River (P0, P1, P2, P3, P4, P5 and P6), Perequê River (PE) and Pilões River (PI).

Physical-chemical parameters such as conductivity, dissolved oxygen (DO), $\mathrm{pH}$, salinity, hardness, total solids, turbidity, LAS surfactants, organic and inorganic carbon and chlorides were monitored from the water samples during this study. All the techniques were carried out according to [10], using electrometric and chemical reaction when possible. The measurements were performed with Hach system HD 40d (DO and conductivity), Micronal B474 (pH), Refactometer Quimis Q-767-3 (salinity); the hardness was measured by volumetric titration.

The samples were collected with suitable plastic containers (superficial samples). At that time samples were divided in aliquots for the measurements of toxicity and physical-chemical parameters. Samples were kept under refrigeration during transportation, and their conservation in Laboratory followed APHA methods [10].

The analysis of some contaminants present in the sediment was performed in the $2^{\text {nd }}$ campaign (August/2010), by Neutronic Activation Analysis. The details of the analytical procedure were described at [11].

\section{Ecotoxicity Assays}

The ecotoxicity assays and the cultivation of the living-organisms followed methods proposed by Brazilian Association of Technical Standards (ABNT-NBR) and they were performed at Biological and Environmental Testing Laboratory, at Radiation Technology Center (IPEN).

The Vibrio fischeri bacteria (acute effects) and Ceriodaphnia dubia (chronic 
toxicity effects) were the exposed organisms during the toxicity assessment on surface waters.

The assay with $V$. fischeri bacteria was performed at Microtox ${ }^{\circledR}$ system, M-500 Microbics, according to [12], using liofilized bacteria. The water samples were diluted to the concentrations: $20.7 \%$; $31.6 \%$; $46.6 \%$ and $70 \%$. Negative control was carried out with standard dilution solution. Initial measurements of bacterial luminescence were performed $\left(I_{0}\right)$ prior to the addition of the water sample. After 15 minutes of bacteria exposure in the water samples, a second series of measurements was carried out $\left(I_{15}\right)$, in order to evaluate if there was negative effects related to the luminescence decreasing. The validation of these assays was performed with phenol as a reference substance. The results were expressed as an effective concentration of the toxicant (EC50) which caused a 50\% reduction in luminescence, after the exposure to the water sample for 15 minutes.

The classification system of [13] was presented in order to discuss the level of toxicity in Cubatão waters, according to EC50 (\%) values: < 25: very toxic; 25 50: toxic; 51 - 75: moderately toxic; > 75: slightly toxic.

The values of EC50 (\%) were obtained from a statistical procedure based on the gamma effect $(\gamma)$ and the water sample concentration $(\mathrm{C} \%)$, version 7.82 statistic program (Microtox ${ }^{\circledR}$ system). The gamma value $(\gamma)$ was calculated from the ratio of lost and remaining luminescence, by the expression:

$$
\gamma=\frac{K F \times I T_{0}}{I T_{t}}-1 \quad K F \equiv \frac{I C_{t}}{I C_{0}}
$$

where $K F$ is a correction factor, $I C_{0}$ and $I T_{0}$ are the intensities of the light emitted initially by bacteria in the control and water sample, while $I C_{t}$ and $I T_{t}$ are the intensities measured after $t$ minutes of contact in the control and water sample, respectively. For each water sample, EC50 (\%) was obtained by linear regression applied to the corresponding linearized curve of the parameter $\gamma$ as a function of the water sample concentration $\mathrm{C} \%$,

$$
\ln (\gamma)=a \cdot \ln (\mathrm{C} \%)+b
$$

with $a$ and $b$ being the angular and linear coefficients of the straight line and $\ln$ is the natural logarithm function. Taking into account that EC50 (\%) corresponds to the concentration which decreased the luminescence in $50 \%$ it follows that if $\gamma=1$ in Equation (1) we have $\mathrm{C} \%=\mathrm{EC} 50(\%)$ and consequently:

$$
\operatorname{EC50}(\%)=\exp \left(-\frac{b}{a}\right) \text {. }
$$

Chronic toxicity assays were carried out using ten replicates of each water sample exposed to Ceriodaphnia dubia. The reproduction and the mortality were registered over three calves ( 7 to 8 days). The validation assays were performed with potassium chloride as reference substance. The number of neonates obtained at each sample was compared to the number obtained in the control. For the assay validation at least 15 neonates should be obtained as an average number in the negative control [14]. 
Statistical analyses were performed with the version 3.5 TOXSTAT program [15] based on the bioequivalence t-test. The bioequivalence constant (B) obtained by [16] for the Ceriodaphnia dubia $(\mathrm{B}=0.79$ ) was used in the calculations. From the data of statistical analysis, the water samples were classified as toxic or non-toxic, after compared with the control.

\section{Results and Discussion}

The chronic and acute toxicity in superficial water was the main target analysis for the monitoring plan during this study. Nonetheless, it was imperative to consider the physical-chemical parameters, once they are very important in keeping life. The final issue was to do some consideration regarding the sediments contamination mainly on the previous report data.

From the obtained results, the physical chemical data was presented at Table 2. Dissolved oxygen variation was quite good $\left(7.5 \mathrm{mg} \cdot \mathrm{L}^{-1}\right.$ up to $\left.7.9 \mathrm{mg} \cdot \mathrm{L}^{-1}\right)$, the same normal variation was noted for $\mathrm{pH}$, salinity and turbidity. The obtained values of organic carbon and inorganic carbon confirmed P0 as the least contaminated, which means in better conditions, when compared to the other monitored sites at Cubatão River. TOC was higher at P1, P2, P3, P4, P5 and P6; probably these sites received more influence from sewage and industrial wastewater, compared to P0, PE and PI. In fact PI (Pilões River) belongs to a forest reserve and $\mathrm{PE}$ is also a cleaner site compared to Cubatão River. Concerning conductivity and hardness of water in Cubatão River, P5 was 6 and 3 times higher than the average numbers of other sites monitored at Cubatão, respectively, which proves the impacts form sewage and industrial wastewater, influencing negatively the numbers at P5. Close to P5 there is Carbocloro Chemical Industries S/A, which is an important contributor for conductivity, hardness and even for the chlorides $\left(74.68 \mathrm{mg} \cdot \mathrm{L}^{-1} \pm 96.59 \mathrm{mg} \cdot \mathrm{L}^{-1}\right.$, at P5). Excluding P0 and P5, the average of chlorides was $42 \mathrm{ppm}$ for Cubatão River. The LAS surfactant contamination in waters was evident but in relatively low concentrations.

No ecotoxicity or chronic effects should be expected at river water, especially at a Level 1 class system, as Cubatão River. Nonetheless, since we know that anthropogenic activities introduced loads of products into the basin, we looked into some data related to superficial waters, some information regarding superficial sediment and their principal contaminants.

The acute toxicity data for $V$. fischeri are shown in Figure 2. Figure 3 and Figure 4 presents statistical analyzes related to the same organism.

From Figure 2 it is possible to confirm toxic effects in all collected samples exposed to $V$. fischeri, EC50 values ranging between $31.28 \%$ and $71.61 \%$, numbers corresponding to the sites $\mathrm{P} 5$ and $\mathrm{P} 0$, respectively. At P0, EC50 values varied from $71.61 \%$ ( $1^{\text {st }}$ campaign) to $36.30 \%$ ( $4^{\text {th }}$ campaign) indicating an increasing toxicity of the water samples to Vibrio fischeri over the studied period. Applying Bulich comparisons system, it was possible to confirm toxicity to majority of samples and three of them as moderately toxic for bacteria. 


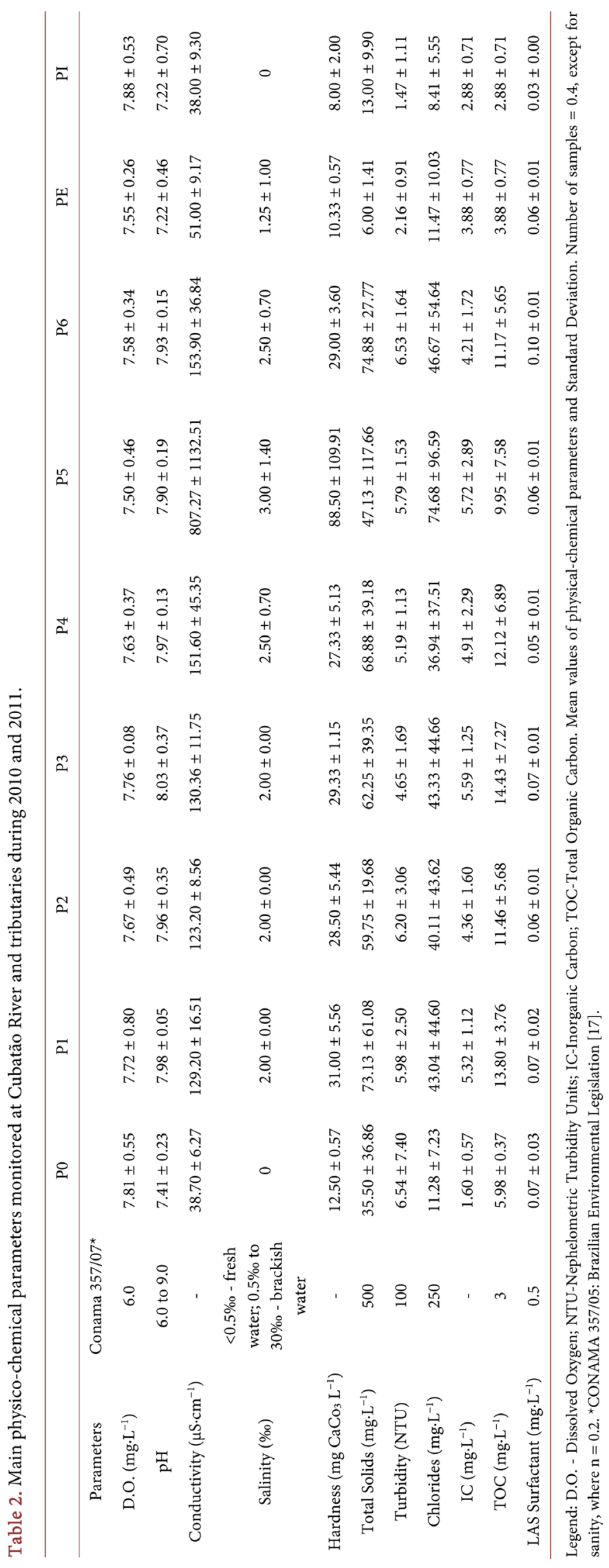




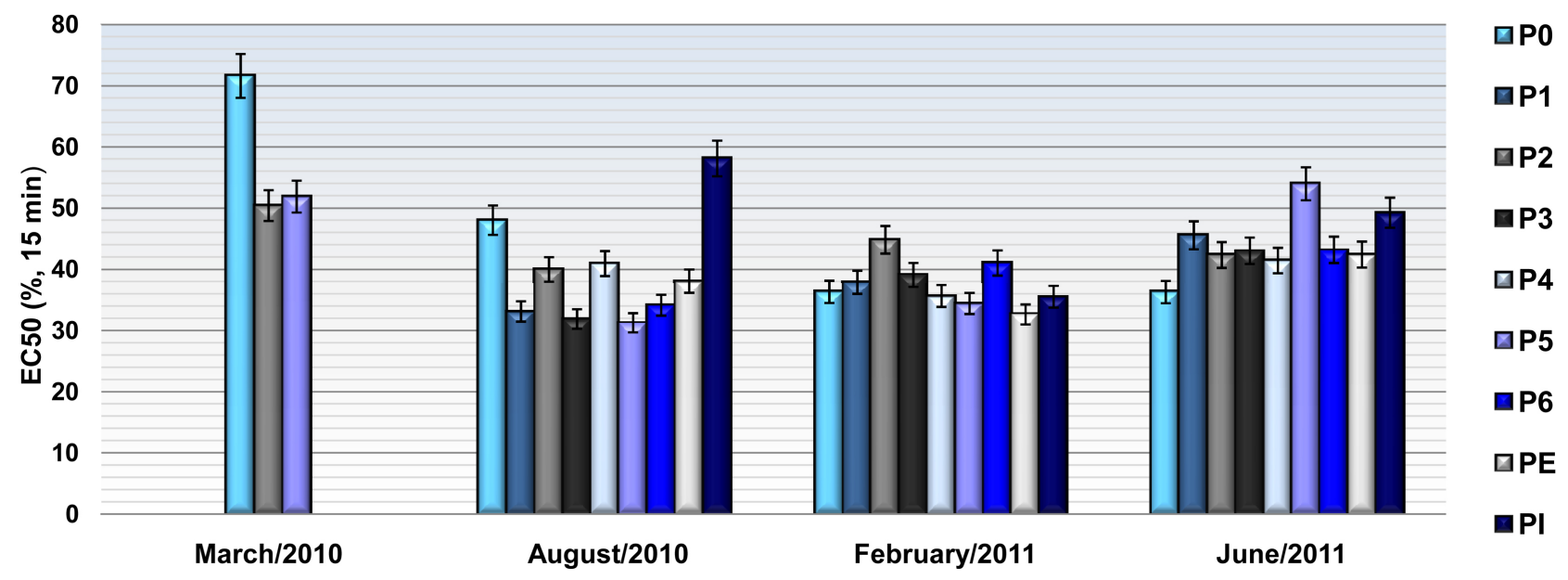

Figure 2. EC50 values (\%) as a function of sampling period ( V. fischeri-15 $\mathrm{min}$ ).

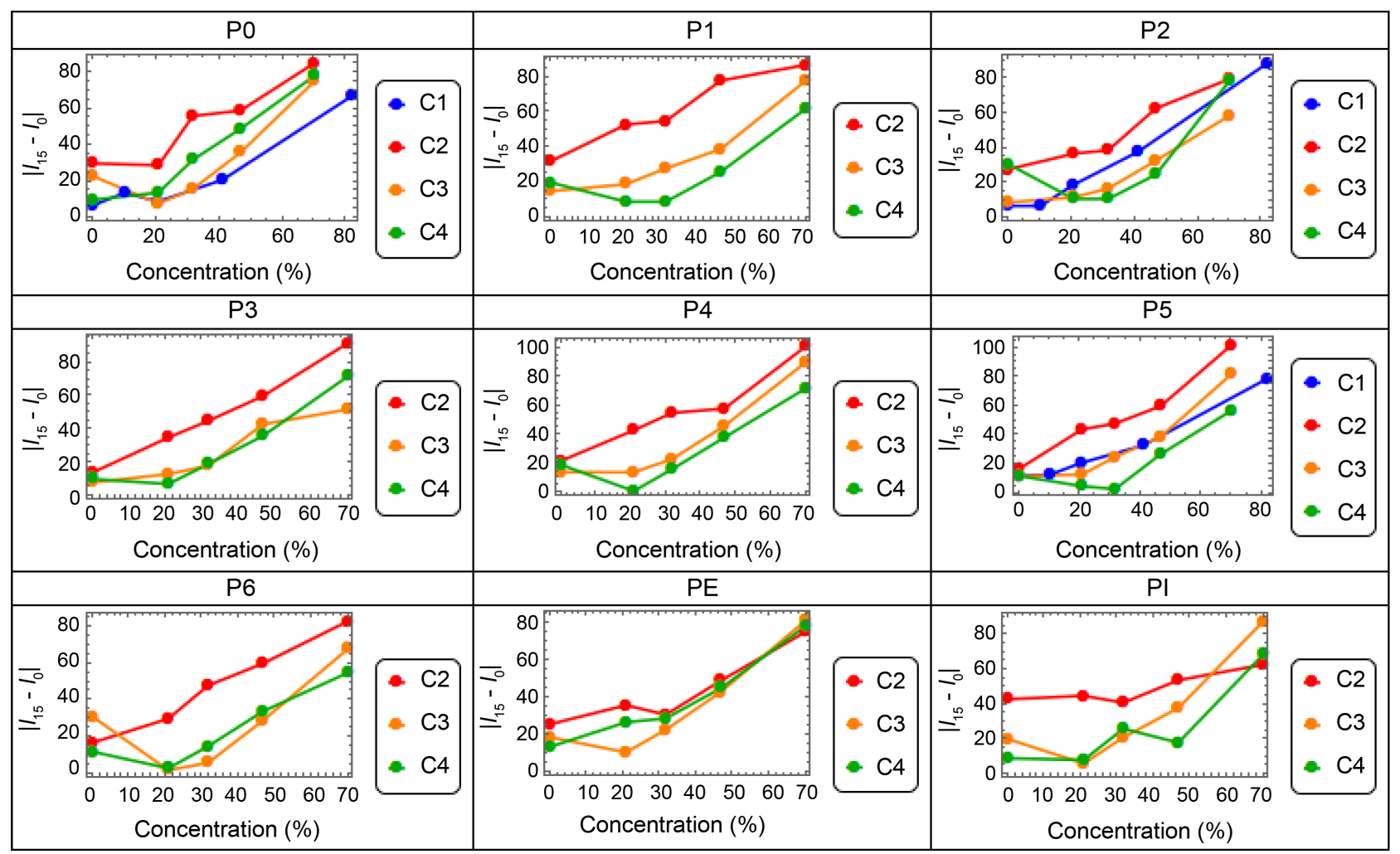

Figure 3. Absolute value of the luminescence variation to Vibrio fischeri, $\left[I_{15}-I_{0}\right]$, as afunction of the water sample concentration for each sampling site and periods of the year. Legend: C1: March/2010; C2: August/2010; C3: February/2011; C4: June/2011.

Notice that during the $1^{\text {st }}$ campaign it was obtained the highest EC50 (\%) in the sampled sites, indicating lower toxicity. This fact may be associated with the rainy season that contributes to a greater dispersion of pollutants. It is also noteworthy that over the study, the higher EC50 (\%) values were 58.13 and 71.61, corresponding to the water samples belonging to the sites PI and P0. In contrast, the lower values of EC50 (\%) were observed in samples from sites P3 and P5 (31.90 and 31.28, respectively). These sites are located in important 


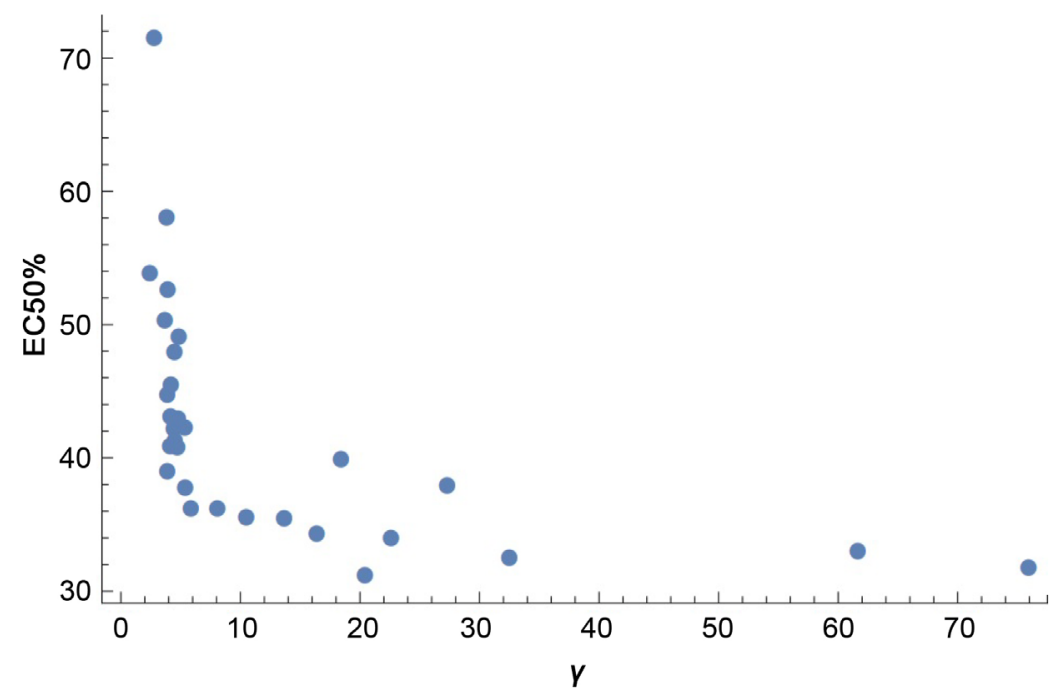

Figure 4. Scatter plot of the values of EC50 (\%) as a function of gamma values associated with the higher concentration samples.

industrialized areas, where P3 is under direct influence of the residual wastewater at Henry Borden plant. P5 site is the closest to Chemical Industries Carbocloro, and it was also representing one of the last sites of the river, considered in this study. This last site was under the influence of all contaminants discharged along the course of the Cubatão River and its tributaries.

A critical analysis of luminescence raw data was carried out in order to widely understand the water system concerning much more than EC50 numbers (Figure 3). The graphs represent the absolute value of the luminescence variation to Vibrio fischeri, as a function of the water sample concentration for each sampling. The analysis of these graphs showed that, for all the sampling sites, the luminescence variation was higher during the $2^{\text {nd }}$ campaign (August 2010).

It was presented the scatter plot of EC50 (\%) as a function of gamma values (Figure 4), associated with the higher concentration samples. It shows a non-linear relationship between the descending and EC50 (\%) range, showing that high toxicity levels correspond to high range of values.

A Pearson correlation analysis was performed with toxicity to $V$. fischeri and the physical chemical parameters. The dissolved oxygen in water showed a moderate positive correlation $(\mathrm{p}=0.540)$, while salinity $(\mathrm{p}=-0.631)$, inorganic carbon $(p=-0.696)$ and total organic carbon $(p=-0.532)$ showed moderate negative correlation. On the other hand, the correlations were weak or very weak for the other physical chemical parameters.

Regarding chronic effects, they were determined with Ceriodaphnia dubia, which were exposed to Cubatão, Perequê and Pilões rivers water, as data shown in Figure 5. The values represent the average of neonates obtained during each assay (March/2010 to June/2011). For all toxicity assays the average number of neonates was higher than 15 , for the control as well as for all samples of the $\mathrm{Cu}$ batão River and its tributaries. Using the " $\mathrm{t}$ " test for bioequivalence, none of 


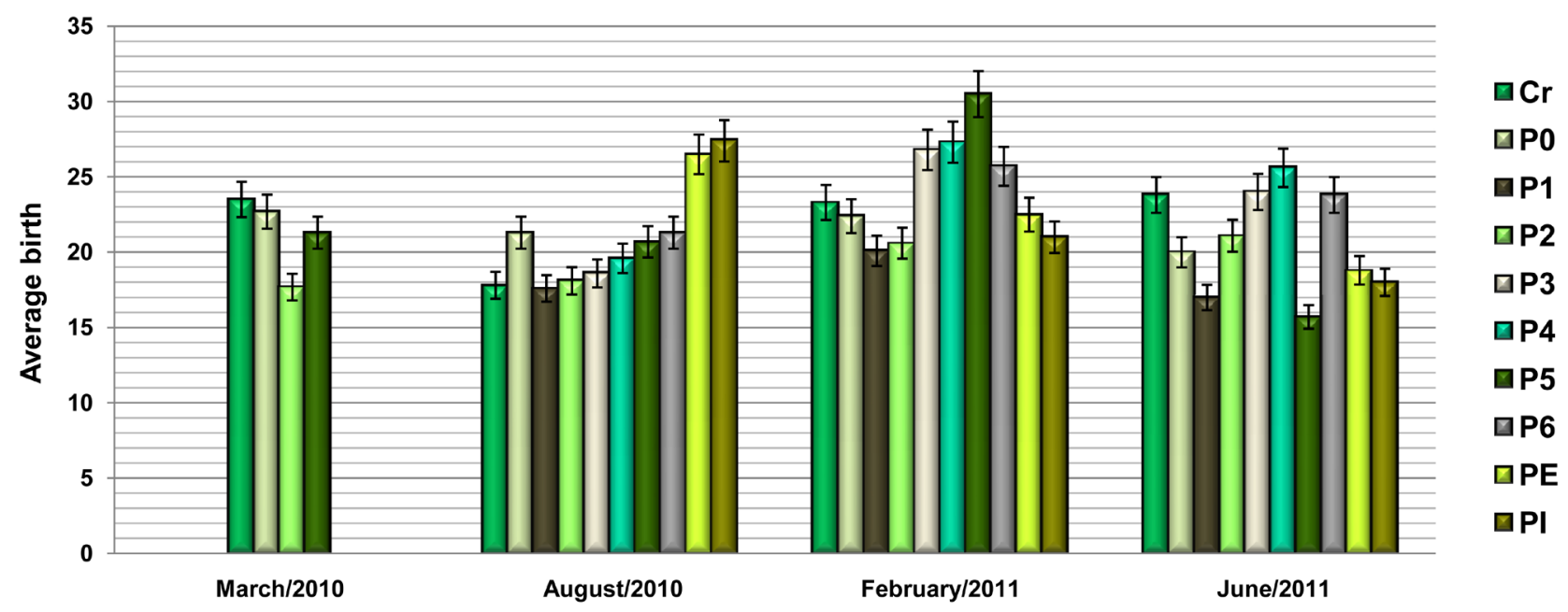

Figure 5. Average neonates of $C$. dubia with standard deviations after exposure to water, versus period (Cr indicates the control site).

the samples showed a significant difference compared to control (mortality/reproduction) and they were not considered toxic.

Chronic effects in C. dubia were not observed during this study. It is easily to note that organic matter was a positive factor during these assays, especially at PI ( $2^{\text {nd }}$ sampling), P4 and P5 ( $3^{\text {rd }}$ sampling).

During the $2^{\text {nd }}$ campaign the highest neonates' averages values were obtained at PE and PI, higher than 26 neonates. A wide variation of values was obtained at dry seasons (August, 2010 and June, 2011). The worst result (15.7 neonates) was obtained at P5, June 2011, showing some effect if compared to the control. At that time, the water conductivity was $2500 \mu \mathrm{s} / \mathrm{cm}$, probably under the influence of Carbocloro Inc., and estuary through the tidal cycle. Comparing both toxicity assays, we may confirm Vibrio fischeri as the most sensitive applied living-organism and in accordance with P5 indicating some negative effect in dry seasons.

Previous studies in the same region evidenced acute and chronic effects for differents organisms: C. dubia, L. variegatus, D. similis, H. Azteca are among the organisms affected by exposure to surface waters and sediments of the region [11] [18] [19] [20].

Data has been showing that Cubatão River is impacted also due to the received water from the Billings reservoir, through discharge Channel II of the Henry Borden, which correspond to sites close to points 1 and 3. It was observed high percentage of results not in accordance with the quality standards for cyanobacteria cells in water [21]. In 2010 (the period of the $1^{\text {st }}$ and $2^{\text {nd }}$ campaigns of this study) and mainly in 2011 (the period of the $3^{\text {rd }}$ and $4^{\text {th }}$ campaigns), there was a high density of cyanobacteria in the river. These results corroborate to the pattern observed in Figure 3, especially with high variation $V$. fischeri luminescence, possibly reducing the luminescence due to biological toxins. Analyzing the reports of subsequent years, there is a worsening of the quality of Cubatão 
River waters due to the presence of cyanobacteria in water: percentages of non-compliant with the quality standards were 100\% (2012 and 2013), 75\% (2014) and 100\% in 2015 [21].

In addition, the influence of contaminants in sediments is also certainly associated to the EC50 numbers determined with $V$. fischeri to all samples. Sediments can be a source of indirect contamination to pelagic organisms by the resuspension of contaminants caused by biological action, storms, dredging, dietary or by the exchange between the interstitial water and overlying water sediments [22].

When sediments of the Cubatão River were monitored, high concentrations of organic compounds were obtained, such as endrin, dibenzene $(\mathrm{a}, \mathrm{h})$ antracene 8.2; 7.2 and $150 \mu \mathrm{g} \cdot \mathrm{kg}^{-1}$ at P5, respectively, in June, 2011. These values do not comply with current environmental recommendations [23]. The same behavior was observed for metal analysis: chrome, zinc and lead 32; 91 and $16 \mathrm{mg} \cdot \mathrm{kg}^{-1}$, respectively. Neutron activation analysis (NAA) was applied to the same sediment samples collected in August, 2010.

The details of the analytical procedure by NAA were already described at [11]. As a criterion for sediment quality evaluation, [24] adopted the values TEL and PEL oriented values, established by the [25] for the total concentration of arsenic, metals and organic compounds, in order to assess possible deleterious effects on the biota. TEL (Threshold Effect Level) indicates the concentration below which there is a rare occurrence of adverse effects to biota and Probable Effect Level (PEL) indicates the concentration above which there is frequent occurrence of adverse effects to biota. When the results for As, $\mathrm{Cr}$ and $\mathrm{Zn}$ were compared to TEL and PEL oriented values, as surpassed the TEL value $\left(5.9 \mathrm{mg} \cdot \mathrm{kg}^{-1}\right)$ in points P0, P4, P5 and PE; only P2 exceeded the PEL value $\left(17.0 \mathrm{mg} \cdot \mathrm{kg}^{-1}\right)$ and PI was lower than TEL value. For Cr, all points surpassed the TEL value (37.3 $\mathrm{mg} \cdot \mathrm{kg}^{-1}$ ) but were lower than PEL value $\left(90 \mathrm{mg} \cdot \mathrm{kg}^{-1}\right)$. For $\mathrm{Zn}$, all results were much lower than TEL value $\left(123 \mathrm{mg} \cdot \mathrm{kg}^{-1}\right)$.

The obtained values for NAA for some trace and rare earth elements were also compared to reference values, Upper Continental Crust (UCC) and North American Shale Composite (NASC) [26]. According to the values presented in Table 3, P5 and PI were the worst, exceeding even the reference values.

Significant differences in values for each contaminant were obtained during the period. Manganese at P0 was very high, followed by PE and P2. Chromium values at PE and PI were higher than the other sites. The same was noted for Zinc at PI, P4 and P5. These data are related to all type of soil occupation in the monitored area, including mining, industrial activity and storm water runoff.

The values for $\mathrm{Cr}\left(52.7-77 \mathrm{mg} \cdot \mathrm{kg}^{-1}\right)$ and $\mathrm{Zn}\left(60-104 \mathrm{mg} \cdot \mathrm{kg}^{-1}\right)$ observed in this study corroborate previous data from the region. [2] demonstrate important values for some elements in sediment samples from Cubatão River: Cr 56 - 72 $\mathrm{mg} \cdot \mathrm{kg}^{-1}$; Cu 30 - $43 \mathrm{mg} \cdot \mathrm{kg}^{-1}, \mathrm{~Pb} 23$ - $34 \mathrm{mg} \cdot \mathrm{kg}^{-1}$ and $\mathrm{Zn} 94$ - $131 \mathrm{mg} \cdot \mathrm{kg}^{-1}$. [4] showed important concentrations of heavy metals in sediments of Cubatão River: $\mathrm{Cr}\left(45 \pm 5 \mathrm{mg} \cdot \mathrm{kg}^{-1}\right) ; \mathrm{Cu}\left(37 \pm 7 \mathrm{mg} \cdot \mathrm{kg}^{-1}\right) ; \mathrm{Zn}\left(94 \pm 12 \mathrm{mg} \cdot \mathrm{kg}^{-1}\right) ; \mathrm{Pb}(22 \pm 4$ 
Table 3. NAA results ( $\mathrm{mg} \cdot \mathrm{kg}^{-1}$ ) (short and long irradiations) for sediment samples (duplicate) of the Cubatão River, (concentration \pm standard deviation), UCC and NASC values. ( $2^{\mathrm{n}}$ campaign: August/2010).

\begin{tabular}{ccccccccccccccc}
\hline Points & \multicolumn{2}{c}{ P0 } & \multicolumn{2}{c}{ P2 } & \multicolumn{2}{c}{ P4 } & \multicolumn{2}{c}{ P5 } & \multicolumn{2}{c}{ PE } & \multicolumn{2}{c}{ PI } \\
\hline Elements & Conc. & SD & Conc. & SD & Conc. & SD & Conc. & SD & Conc. & SD & Conc. & SD & UCC & NASC \\
\hline As & 11.4 & 0.3 & 21.2 & 0.5 & 11.5 & 0.3 & 6.6 & 0.2 & 11.9 & 0.3 & 5.4 & 0.3 & $\mathbf{2}$ & $\mathbf{2}$ \\
Ce & 69.0 & 2.0 & 75.5 & 2.2 & 97.0 & 2.9 & 202 & 6.2 & 81.5 & 1.3 & 319 & 5 & $\mathbf{6 5 . 7}$ & $\mathbf{7 3}$ \\
Cr & 52.7 & 1.0 & 71.3 & 1.3 & 76.9 & 1.4 & 56.4 & 1.0 & 77.0 & 1.5 & 76.9 & 1.5 & $\mathbf{3 5}$ & $\mathbf{1 2 5}$ \\
Hf & 6.5 & 0.2 & 8.7 & 0.3 & 11.5 & 0.4 & 17.0 & 0.6 & 10.3 & 0.4 & 32.8 & 1.2 & $\mathbf{5 . 8}$ & $\mathbf{6 . 3}$ \\
La & 31.4 & 0.3 & 38.1 & 0.4 & 46.1 & 0.5 & 79.9 & 1.3 & 39.3 & 0.6 & 163 & 2.4 & $\mathbf{3 2 . 3}$ & $\mathbf{3 2}$ \\
Mn & 979 & 66 & 679 & 35 & 590 & 91 & 457 & 45 & 832 & 10 & 555 & 57 & $\mathbf{5 2 7}$ & $\mathbf{4 6 5}$ \\
Nd & 31 & 3 & 34 & 4 & 45 & 4 & 68 & 5 & 15 & 2 & 143 & 11 & $\mathbf{2 5 . 9}$ & $\mathbf{2 7 . 4}$ \\
Sm & 4.9 & 0.1 & 6.2 & 0.1 & 7.8 & 0.1 & 15.9 & 0.2 & 6.8 & 0.1 & 25.0 & 0.5 & $\mathbf{4 . 7}$ & $\mathbf{5 . 7}$ \\
Ta & 0.9 & 0.2 & 1.1 & 0.2 & 1.4 & 0.1 & 1.4 & 0.2 & 0.77 & 0.05 & 1.1 & 0.1 & $\mathbf{1 . 5}$ & $\mathbf{1 . 1 2}$ \\
Tb & 0.7 & 0.1 & 0.8 & 0.1 & 1.0 & 0.1 & 2.1 & 0.1 & 1.2 & 0.1 & 3.3 & 0.2 & $\mathbf{0 . 5}$ & $\mathbf{0 . 8 5}$ \\
Th & 12.5 & 0.2 & 15.5 & 0.3 & 19.0 & 0.3 & 28.6 & 0.7 & 15.6 & 0.3 & 51.6 & 1.0 & $\mathbf{1 0 . 3}$ & $\mathbf{1 2}$ \\
U & 2.7 & 0.1 & 3.2 & 0.2 & 3.7 & 0.2 & 5.4 & 0.1 & 3.0 & 0.1 & 9.7 & 0.2 & $\mathbf{2 . 5}$ & $\mathbf{2 . 7}$ \\
Zn & 60 & 3 & 75 & 3 & 99 & 3 & 77 & 3 & 72 & 3 & 104 & 4 & $\mathbf{5 2}$ & $\mathbf{8 5}$ \\
\hline
\end{tabular}

$\left.\mathrm{mg} \cdot \mathrm{kg}^{-1}\right)$. [5] also report significant values in the Cubatão River Basin, highlighting high enrichment near the Cubatão Industrial Complex, due to petrochemical and steel industry activities, as values for $\mathrm{Pb}\left(0.93-7.30 \mathrm{mg} \cdot \mathrm{kg}^{-1}\right)$, for example.

Results obtained with Ceriodaphnia in this study were significant and revealed the use of organic compounds by the cladocera, when more than 25 neonates were born during the assays in the Cubatão water (PI - $2^{\text {nd }}$ sampling, P4 and P5 $3^{\text {rd }}$ sampling). Vibrio fischeri assays were very effective for evidencing potential of pollutants bad effects to biota in the region. This type of data is showing the importance of using different biological levels of organisms for Cubatão monitoring, even using a target organism considered as a screening assay. The time of exposure is also veryimportant for rivers toxicity assessment in the case of environmental emergencies such as for the spillage of chemicals. Concerning screening assays and techniques, [27] also reported types of screening approaches for monitoring emerging pollutants, EPs, using important data from european countries.

The impact of contaminants in aquatic ecosystems was reported in different studies. [28] demonstrated high concentrations of iron, copper and cadmium (21.5, 3.3 and $0.14 \mathrm{mg} \cdot \mathrm{L}^{-1}$, respectively) in the water of Nakivubo wetland (Uganda). [29] accredited the presence of high concentrations of metals such as lead $\left(6000 \mathrm{mg} \cdot \mathrm{kg}^{-1}\right)$ and zinc $\left(8000 \mathrm{mg} \cdot \mathrm{kg}^{-1}\right)$ in surface water from Biala Przemsza river (Poland), to the development of the mining industry and metallurgy. [30] highlight physical degradation by organic particles and suspended minerals as well as the chemical degradation by heavy metals, in rivers of industrial area of Bétaré-Oya (Cameroon). The significant presence of herbicides 
such as atrazine ethofumesate, metolachlor, terbuthylazine in Tagus River Basin waters, with maximum values of $32.63 \mu \mathrm{g} \cdot \mathrm{L}^{-1}$, and effects on the growth of $P$. subcapitata and D. magna lethality were evidenced by [31]. The presence of metals in fish liver tissue (Clarias Gariepinus) of the Nile River and its tributaries was reported by [32], particularly in concentrations of: $\mathrm{Zn}\left(42.48 \mathrm{mg} \cdot \mathrm{kg}^{-1}\right), \mathrm{Fe}$ (51.72 mg. $\left.\mathrm{kg}^{-1}\right), \mathrm{Cu}\left(10.64 \mathrm{mg} \cdot \mathrm{kg}^{-1}\right)$ and $\mathrm{Pb}\left(13.8 \mathrm{mg} \cdot \mathrm{kg}^{-1}\right)$. In Australian river monitoring, organic contaminants, such as pesticides, personal care products and drugs were identified in $92 \%$ of the samples analyzed. Salicylic acid, paracetamol, carbamazepine and caffeine are among the compounds found in waters [33].

Our data may be related to the wide range of contaminants possibly present in the studied basin and to organics compounds, today reported as emerging pollutants, their metabolities and transformation products. EPs, hormones, metals, pyrethroids and certain organophosphorus pesticides affect the aquatic environment at extremely low concentrations and need analytical methods with correspondingly low detection limits [34].

\section{Conclusion}

Indicative of negative effects were demonstrated through the decreasing luminescence of $V$. fischeri exposed to waters from several sampled sites, especially in August/2010 and June/2011. No chronic effects were obtained for $C$. dubia through statistical analysis but there were some indicatives on decreasing neonates after being exposed to Cubatão water, samples P1, P2, P4 and P5. Chlorides in water (at $\mathrm{P} 5=74.68 \pm 96.59 \mathrm{mg} \cdot \mathrm{L}^{-1}$ ) were 1.7 times higher than the average measured at Cubatão River. Water conductivity and hardness were very high at P5. The needs for actions in order to preserve Cubatão River justify monitoring toxicity programs and public participation into decisions for urgent preservation. The Cubatão River basin is of extreme importance for the water supply to the population and the industrial center of the Baixada Santista region.

\section{Acknowledgements}

The authors thank CNPq for the grants (Brazilian Research Council) and also the Fundespa Agency.

\section{References}

[1] Lamparelli, M.L., Costa, M.P., Prósperi, V.A., Bevilácqua, J.E., Araújo, R.P.A., Eysink, G.G.L. and Pompéia, S. (2001) Sistema Estuarino de Santos e São Vicente. In: Relatório Técnico CETESB, São Paulo.

[2] Silva, P.S.C., Mazzilli, B. P. and Fávaro, D.I.T. (2006) Distribution of Radionuclides and Elements in Cubatão River sediments. Journal of Radioanalytical and NuclearChemistry, 269, 767-771. https://doi.org/10.1007/s10967-006-0258-7

[3] Silva, P.S.C., Damatto, S.R., Maldonado, C., Fávaro, D.I.T. and Mazzilli, B.P. (2011) Metal Distribution in Sediment Cores from São Paulo State Coast, Brazil. Marine Pollution Bulletin, 62, 1130-1139. https://doi.org/10.1016/j.marpolbul.2011.02.046 
[4] Luiz-Silva,W., Matos, R.H.R., Kristoch, G.C. and Machado, W. (2006) Variabilidade espacial e sazonal da concentração de elementos-traço em sedimentos do sistema estuarino Santos-Cubatão. Química Nova, 29, 256-263. https://doi.org/10.1590/S0100-40422006000200016

[5] Kim, B.S.M., Salaroli, A.B., Ferreira, P.A.L., Sartoretto, J.R., Mahiques, M.M. and Figueira, R.C.L. (2016) Spatial Distribution and Enrichment Assessment of Heavy Metals in Surface Sediments from Baixada Santista, Southeastern Brazil. Marine Pollution Bulletin, 103, 333-338. https://doi.org/10.1016/j.marpolbul.2015.12.041

[6] Kirschbaum, A.A., Seriani, R., Pereira, C.D.S., Assunção, A., Abessa, D.M.S., Rotundo, M.M. and Ranzani-Paiva, M.J.T. (2009) Cytogenotoxicity Biomarkers in Fat Snook Centropomus Parallelus from Cananéia and São Vicente Estuaries, SP, Brazil. Genetics and Molecular Biology, 32, 151-154. https://doi.org/10.1590/S1415-47572009005000007

[7] Seriani. R., Abessa, D.M.S., Pereira, C.D.S., Kirschbaum, A.A., Assunção, A. and Ranzani-Paiva, M.J.T. (2013) Influence of Seasonality and Pollution on the Hematological Parameters of the Estuarine Fish Centropomus Parallelus. Brazilian Journal of Oceanography, 61, 105-111. https://doi.org/10.1590/S1679-87592013000200003

[8] Buruaem, L.M., Castro, I.B., Hortellani, M.A., Taniguchi, S., Fillmann, G., Sasaki, S.T., Petti, M.A.V., Sarkis, J.E.S., Bícego, M.C., Maranho, L.A., Davanso, M.B., Nonato, E.F., Cesar, A., Costa-Lotufo, L.V. and Abessa, D.M.S. (2013) Integrated Quality Assessment of Sediments from Harbour Areas in Santos-São Vicente Estuarine System, Southern Brazil. Estuarine, Coastal and Shelf Science, 130, 179-189. https://doi.org/10.1016/j.ecss.2013.06.006

[9] Martins, C.C., Bícego, M.C., Mahiques, M.M., Figueira, R.C.L., Tessler, M.G. and Montane, R.C. (2010) Depositional History of Sedimentary Linear Alkylbenzenes (LABs) in a Large South American Industrial Coastal Area (Santos Estuary, Southeastern Brazil). Environmental Pollution, 158, 3355-3364. https://doi.org/10.1016/j.envpol.2010.07.040

[10] American Public Health Association (APHA) (2005) Standard Methods for the Examination of Water \& Wastewater. 21st Edition. Centennial Edition. In: Eaton, A.D., Clesceri, L.S., Rice, E.W. and Greenberg, A.E., Eds., NW, Washington, DC, 20001-3710.

[11] Fávaro, D.I.T., Alegre, G.F., Borrely, S.I., Vukan, W., Vieira, A.S. and Oliveira, S.M.B. (2014) Major and Trace Element Assessment of Tiete River SEDIMENTS, São Paulo, Brazil. Journal of Radioanalytical and Nuclear Chemistry, 299, 977-805. https://doi.org/10.1007/s10967-013-2702-9

[12] ABNT. Associação Brasileira de Normas Técnicas (2006) Ecotoxicologia aquática -Determinação do efeito inibitório de amostras de água sobre a emissão de luz de Vibrio fischeri. ABNT NBR 15411-2, Rio de Janeiro.

[13] Bullich, A.A. (1992) A Practical and Reliable Method for Monitoring the Toxicity of Aquatic Samples. Process Biochemistry, 17, 45-47.

[14] ABNT. Associação Brasileira de Normas Técnicas (2005) Ecotoxicologia aquática-Toxicidade aguda-Método de ensaio com Ceriodaphnia spp (Cladocera, Crustacea). ABNT NBR 13373. Rio de Janeiro.

[15] Gulley, D. and Toxstat 3.5. (1996) West Inc. University of Wyoming. Cheyenne, Wyoming.

[16] Bertoletti, E., Buratini, S.V., Prospéri, V.A.; Araújo, R.P.A. and Werner, L.I. (2007) Selection of Relevant Effect Levels for Using Bioequivalence Hypothesis Testing. 
Journal of the Brazilian Society of Ecotoxicology, 2, 139-145. https://doi.org/10.5132/jbse.2007.02.006

[17] CONAMA Conselho Nacional do Meio Ambiente (2005) Ministério do Meio Ambiente. Resolução N 357, march 17.

[18] Pusceddu, F.H., Alegre, G.F., Pereira, C.D.S. and Cesar, A. (2007) Avaliação da Toxicidade do Sedimento do Complexo Estuarino de Santos Empregando Ouriços-do-mar Lytechinus variegatus (Echinoidea: Echinodermata). Journal of the Brazilian Society of Ecotoxicology, 2, 237-242. https://doi.org/10.5132/jbse.2007.03.005

[19] Moreira, L.B., Cesar, A., Cortez, F.S., Pereira, C.D.S. and Morais, R.D. (2008) Toxicidade nos rios Cubatão e Quilombo, Cubatão (SP). Revista Ceciliana, 30, 31-44.

[20] Garcia, V.S.G., Mesquita, L.C.A., Santos, D.R.A. and Borrely, S.I. (2014) Toxicity Assessment into Sediments from Cubatão River-SP. O Mundo da Saúde, 38, 56-65.

[21] CETESB Companhia de Tecnologia de Saneamento Ambiental (2016) Relatório de Qualidade das águas Interiores no Estado de São Paulo, 2015. São Paulo.

[22] Power, E.A. and Chapman, P.M. (1992) Assessing Sediment Quality. In: Burton Jr., G.A., Ed., Sediment Toxicity Assessment, Lewis Publishers, Boca Raton.

[23] CONAMA Conselho Nacional do Meio Ambiente (2004) Ministério do Meio Ambiente. Resolução N 344, 25 March.

[24] COMPANHIA DE TECNOLOGIA DE SANEAMENTO AMBIENTAL (CETESB). Qualidade de Sedimentos. http://www.cetesb.sp.gov.br

[25] CCME Canadian Environmental Quality Guidelines. https://www.elaw.org/system/files/sediment_summary_table.pdf

[26] Wedepohl, K.H. (1995) The Composition of the Continental Crust. Geochimica et Cosmochimica Acta, 59, 1217-1232. https://doi.org/10.1016/0016-7037(95)00038-2

[27] Geissen, V., Mol, H., Klumpp, E., Umlaug, G., Nadal, M., Ploeg, M.V.D., Zee, S.E.A.T.M.V. and Ritsema, C. J. (2015) Emerging Pollutants in the Environment: A Challenge for Water Resource Management. International Soil and Water Conservation Research, 3, 57-65. https://doi.org/10.1016/j.iswcr.2015.03.002

[28] Fuhrimann, S., Stalder, M., Winkler, M.S., Niwagaba, C.B., Babu, M., Masaba, G., Kabatereine, N.B., Halage, A.A., Schneeberger, P.H.H., Utzinger, J. and Cissé, G. (2015) Microbial and Chemical Contamination of Water, Sediment and Soil in the Nakivubo Wetland Area in Kampala, Uganda. Environmental Monitoring and Assessment, 187, 475. https://doi.org/10.1007/s10661-015-4689-x

[29] Jabłońska-Czapla, M., Nocoń, K., Szopa, S. and Lyko, A. (2016) Impact of the Pb and $\mathrm{Zn}$ Ore Mining Industry on the Pollution of the Biała Przemsza River, Poland. Environmental Monitoring and Assessment, 188, 262.

[30] Rakotondrabe, F., Ngoupayou1, J.R.N., Mfonka, Z., Rasolomanana, E.H., Abolo, A.J.N., Asone, B.L., Ako, A.A. and Rakotondrabe, M.H. (2017) Assessment of Surface Water Quality of Bétaré-Oya Gold Mining Area (East-Cameroon). Journal of Water Resource and Protection, 9, 960-984. https://doi.org/10.4236/jwarp.2017.98064

[31] Silva, E., Pereira, A.C., Estalagem, S.P., Moreira-Santos, M., Ribeiro, R. and Cerejeira, M.J. (2012) Assessing the Quality of Freshwaters in a Protected Area within the Tagus River Basin District (Central Portugal). Journal of Environmental Quality, 41, 1413-1426.

[32] Osman, A.G.M. and Kloas, W. (2010) Water Quality and Heavy Metal Monitoring 
in Water, Sediments, and Tissues of the African Catfish Clarias Gariepinus (Burchell, 1822) from the River Nile, Egypt. Journal of Environmental Protection, 1, 389-400. https://doi.org/10.4236/jep.2010.14045

[33] Scott, P.D., Bartkow, M., Blockwell, S.J., Coleman, H.M., Khan, S.J., Lim, R., McDonald, J.A., Nice, H., Nugegoda, D., Pettigrove, V., Tremblay, L.A., Warne, M.S. and Leusch, F.D. (2014) A National Survey of Trace Organic Contaminants in Australian Rivers. Journal Environment Quality, 43, 1702-1712.

https://doi.org/10.2134/jeq2014.01.0012

[34] Von der Ohe, P.C., Dulio, V., Slobodnik, J., De Deckere, E., Kuhne, R. and Ebert, R.U. (2011) A New Risk Assessment Approach for the Prioritization of 500 Classical and Emerging Organic Microcontaminants as Potential River Basin Specific Pollutants under the European Water Framework Directive. Science of the Total Environment, 409, 2064-2077. https://doi.org/10.1016/j.scitotenv.2011.01.054 